\title{
Pertumbuhan dan Hasil Kedelai di Lahan Rawa Lebak dengan Aplikasi Pupuk Hayati dan Kimia
}

\section{Soybean Growth and Yield in Lowland Swamp with Application of Biological and Chemical Fertilizers}

\author{
Endriani $^{1,2}$, Munif Ghulamahdi ${ }^{*}$, dan Eko Sulistyono ${ }^{3}$
}

\author{
${ }^{1}$ Program Studi Agronomi dan Hortikultura, Sekolah Pascasarjana, Institut Pertanian Bogor \\ ${ }^{2}$ Balai Pengkajian Teknologi Pertanian Lampung \\ Jl.H.Z.A. Pagar Alam No.1A Rajabasa, Bandar Lampung 35145, Indonesia \\ ${ }^{3}$ Departemen Agronomi dan Hortikultura, Fakultas Pertanian, Institut Pertanian Bogor \\ (Bogor Agricultural University), Jl. Meranti, Kampus IPB Darmaga, Bogor 16680, Indonesia
}

Diterima 29 Desember 2016/Disetujui 7 Maret 2017

\begin{abstract}
Soybean (Glycine max L. Merrill) demand is high in Indonesia, however national production is low, therefore improving productivity is important. The research was aimed to determine the effect of application of biofertilizer containing $N$ - fixing and P-solubilizing bacteria on the growth and production of soybean in lowland swamp. The experiment was conducted at Labuhan Ratu VI Village, District of Labuhan Ratu, East Lampung Regency from September to December 2014. The experiment was arranged in factorial randomized block design with three replications. $N$ and $P$ fertilizers were applied in four levels. Doses of $N$ were 0, 11.25, 22.50, $33.75 \mathrm{~kg} \mathrm{ha}^{-1}$, doses of P were 0,36,72, $108 \mathrm{P2O5} \mathrm{kg} \mathrm{ha}^{-1}$, in combination with and without biofertilizer application. The results showed that interaction between biofertilizer and $N$ significantly affected number of branches and number of leaves at maximum vegetative phase. The influence of three types of fertilizer had no significant effect on the productivity of soybean in lowland swamp with soil $p H$ of 7.0 and medium soil fertility. It is recommended to apply Biofertilizer $+11,25 \mathrm{~kg} \mathrm{~N} \mathrm{ha}^{-1}+36 \mathrm{~kg} P 2 \mathrm{O} 5 \mathrm{ha}^{-1}$ to obtain high soybean production in lowland swamp area.
\end{abstract}

Keywords: nitrogen, phosphate, productivity, soil fertility

\section{ABSTRAK}

Kedelai (Glycine max (L). Merr.) merupakan komoditas yang perlu mendapat perhatian karena kebutuhan dalam negeri cukup tinggi, sementara luas panen dan produksi kedelai terus menurun sehingga impor terus meningkat. Tujuan penelitian adalah untuk mendapat informasi pengaruh pupuk hayati penambat $N$ dan pelarut $P$ terhadap pertumbuhan dan produksi kedelai serta interaksi pupuk N,P, dan pupuk hayati pada kedelai di lahan rawa lebak. Penelitian dilaksanakan di Desa Labuhan Ratu VI Kecamatan Labuhan Ratu, Kabupaten Lampung Timur dari September hingga Desember 2014. Percobaan disusun menggunakan rancangan acak kelompok faktorial dengan tiga ulangan. Pupuk nitrogen dan fosfat diterapkan dalam empat level dosis. Dosis $\mathrm{N}$ adalah 0, 11,25, 22,50, dan 33,75 kg ha-1. Dosis P adalah 0, 36, 72, dan $108 \mathrm{~kg} \mathrm{P}_{2} \mathrm{O}_{5} \mathrm{ha}^{-1}$, pupuk hayati terdiri dari 2 perlakuan, dengan pupuk hayati dan tanpa pupuk hayati. Hasil penelitian menunjukkan interaksi pupuk hayati dan $N$ secara nyata berpengaruh terhadap komponen pertumbuhan pada fase vegetatif maksimum,yaitu jumlah cabang dan jumlah daun. Interaksi ketiga jenis pupuk tidak berpengaruh nyata terhadap produktivitas tanaman kedelai di lahan rawa lebak dengan $p H$ tanah 7.0 dan tingkat kesuburan tanah sedang. Untuk menghasilkan kedelai dengan produksi tinggi pada lahan rawa lebak, dosis yang direkomendasikan adalah pupuk hayati $+11.25 \mathrm{~kg} \mathrm{~N} \mathrm{ha-1}+36 \mathrm{~kg} \mathrm{P}_{2} \mathrm{O}_{5} \mathrm{ha}^{-1}$.

Kata kunci: nitrogen, phosfat, produktivitas, kesuburan tanah

\section{PENDAHULUAN}

Kedelai (Glycine max (L.) Merr) merupakan komoditas yang perlu mendapat perhatian karena kebutuhan dalam

\footnotetext{
* Penulis untuk korespondensi. e-mail: mghulamahdi@yahoo.com
}

negeri cukup tinggi, mencapai 2.02 juta ton per tahun, sementara produksi nasional tahun 2016 hanya 963,183 ton (BPS, 2016). Luas panen kedelai terus menurun sementara produksi dalam negeri tidak mencukupi sehingga impor terus meningkat.

Salah satu upaya peningkatan produksi kedelai adalah perluasan areal tanam pada lahan rawa lebak. Menurut 
Mulyani dan Sarwani (2013) lahan rawa lebak merupakan lahan sub optimal yang secara alamiah mempunyai produktivitas rendah karena faktor internal dan eksternal. Lahan rawa lebak dipengaruhi oleh adanya genangan dengan lama genangan $\geq 3$ bulan dan tinggi genangan $\geq 50 \mathrm{~cm}$.

Masalah yang dihadapi dalam pengembangan lahan rawa lebak adalah pengendalian air, $\mathrm{pH}$ tanah pada umumnya rendah, dan ketersediaan unsur hara dalam tanah relatif rendah dengan tingkat kesuburan tanah yang rendah sampai sedang (Haryono et al., 2013). Oleh karena itu diperlukan teknologi budidaya yang dapat menaikkan $\mathrm{pH}$ tanah dan meningkatkan kesuburan tanah yakni teknologi kombinasi pemupukan kimia dan hayati dan ameliorasi lahan serta pengelolaan air yang tepat dengan sistem budidaya jenuh air.

Budidaya jenuh air yaitu pemberian air terus-menerus sejak tanam sampai matang fisiologis. Air dialirkan melalui parit di antara petak tanaman dengan permukaaan air tetap sekitar 10-20 cm di bawah permukaaan tanah. Budidaya jenuh air dapat memperbaiki pertumbuhan, meningkatkan serapan hara dan meningkatkan produksi kedelai dibandingkan budidaya kering (Ghulamahdi et al., 2009; Sagala et al., 2011). Ketersediaan unsur hara yang rendah di lahan rawa lebak memerlukan input pupuk kimia dan hayati untuk mendapatkan hasil yang optimal.

Pupuk hayati memiliki prospek yang bagus untuk dikembangkan dan saat ini semakin diminati oleh petani karena selain ramah lingkungan, juga dapat meningkatkan produktivitas tanaman. Pupuk hayati merupakan formula pupuk berisi mikroba, baik tunggal maupun beberapa mikroba dalam satu bahan pembawa dengan fungsi untuk menyediakan unsur hara dan meningkatkan produksi tanaman (Simanungkalit et al., 2001).

Pupuk hayati yang digunakan mengandung beberapa bakteri penambat $\mathrm{N}$ dan pelarut $\mathrm{P}$ (Bradhyzobium japonicum, Azotobacter vinelandi, Methylobacterium SP dan Bacilus cereus). Pemanfaatan bakteri pelarut fosfat yang berperan dalam penyuburan tanah karena mampu melakukan mekanisme pelarutan fosfat dengan mengekskresikan sejumlah asam organik (Ilham et al., 2014). Pemanfaatan bahan pembenah tanah dan pupuk untuk memperbaiki kesuburan tanah dapat dilakukan dengan penambahan kapur, bahan organik dan pupuk NPK (Taufiq et al., 2011). Menurut Mulyadi (2012) pemberian legin, pupuk NPK (15:15:15) dan urea dapat meningkatkan kandungan hara $\mathrm{N}, \mathrm{P}$ total pucuk dan pembentukan bintil akar kedelai. Penelitian kombinasi pupuk hayati dan pupuk kimia dengan sistem budidaya jenuh air di lahan rawa lebak perlu dilakukan untuk meningkatkan pertumbuhan dan produksi kedelai. Pendekatan terpadu dengan menggunakan kombinasi pupuk hayati dan pupuk kimia merupakan pendekatan yang baik. Berdasarkan latar belakang yang dikemukakan maka tujuan penelitian adalah 1) mendapat informasi pengaruh pupuk hayati bakteri penambat $\mathrm{N}$ dan pelarut $\mathrm{P}$ terhadap pertumbuhan dan produksi kedelai di lahan rawa lebak, 2) mengetahui interaksi pupuk $\mathrm{N}, \mathrm{P}$, dan pupuk hayati terhadap pertumbuhan dan produksi kedelai di lahan rawa lebak.

\section{BAHAN DAN METODE}

Penelitian dilaksanakan di lahan rawa lebak dangkal Desa Labuhan Ratu VI, Kecamatan Labuhan Ratu, Kabupaten Lampung Timur, Lampung, dari bulan September sampai Desember 2014. Bahan yang dipergunakan adalah benih kedelai varietas Tanggamus, pupuk Urea, SP-36, KCl, dolomit, pupuk hayati, herbisida, pestisida, dan insektisida kimia. Bahan-bahan kimia untuk analisis tanah dan analisis hara di laboratorium. Alat yang digunakan adalah alat-alat budidaya serta alat laboratorium untuk analisis tanah dan analisis hara tanaman. Penelitian menggunakan rancangan faktorial dalam rancangan lingkungan acak kelompok terdiri dari 3 faktor dengan 3 ulangan. Faktor pertama adalah level dosis pupuk $\mathrm{N}$ (Urea) yang terdiri atas 4 taraf yaitu $\mathrm{N} 0=$ tanpa pupuk $\mathrm{N}, \mathrm{N} 1=11.25 \mathrm{~kg} \mathrm{~N} \mathrm{ha}^{-1}, \mathrm{~N} 2=22.50 \mathrm{~kg} \mathrm{~N} \mathrm{ha}^{-1}$, $\mathrm{N} 3=33.75 \mathrm{~kg} \mathrm{~N} \mathrm{ha}^{-1}$. Faktor kedua yaitu dosis pupuk $\mathrm{P}$ (SP36) terdiri dari 4 taraf yaitu $\mathrm{P} 0=$ tanpa pupuk $\mathrm{P}, \mathrm{P} 1=36 \mathrm{~kg}$ $\mathrm{P}_{2} \mathrm{O}_{5}$ ha $^{-1}, \mathrm{P} 2=72 \mathrm{~kg} \mathrm{P}_{2} \mathrm{O}_{5}$ ha $^{-1}, \mathrm{P} 3=108 \mathrm{~kg} \mathrm{P}_{2} \mathrm{O}_{5}$ ha $^{-1}$. Faktor ketiga yaitu Pupuk hayati penambat $\mathrm{N}$ dan pelarut $\mathrm{P}, \mathrm{A} 0=$ tanpa pupuk hayati, $\mathrm{A} 1=$ dengan pupuk hayati. Peubah yang diamati terdiri atas komponen pertumbuhan dan komponen produksi tanaman. Komponen pertumbuhan meliputi tinggi tanaman pada umur 4 MST dan 8 MST, jumlah daun 8 MST, jumlah cabang pada 8 MST dan 10 MST, kadar hara $\mathrm{N}$, P, dan $\mathrm{K}$ daun pada umur 8 MST. Komponen produksi meliputi jumlah polong total, jumlah polong isi, jumlah polong hampa, bobot kering tajuk, bobot kering biji dan produktivitas. Data yang diperoleh dari hasil pengamatan dianalisis dengan uji F, apabila terdapat pengaruh yang nyata dilanjutkan dengan uji DMRT (Duncan Multiple Range Test) untuk melihat perbedaan antar perlakuan pada taraf $\alpha 0.05$.

\section{HASIL DAN PEMBAHASAN}

\section{Kondisi Umum Lahan Penelitian}

Hasil analisis tanah sebelum penelitian menunjukkan bahwa tanah bereaksi netral $\left(\mathrm{pH} \mathrm{H}_{2} \mathrm{O}\right.$ 7.0), N-total tanah sangat rendah $(0.05 \%), \mathrm{P}_{2} \mathrm{O}_{5}$ yang sangat tinggi (74 mg $\left.100 \mathrm{~g}^{-1}\right), \mathrm{K}_{2} \mathrm{O}$ yang sedang $\left(26 \mathrm{mg} 100 \mathrm{~g}^{-1}\right)$ tergolong tingkat kesuburan tanah sedang. Tekstur tanah lempung liat berpasir, dengan kandungan pasir 53\%, debu 25\%, liat $22 \%$ (Balittanah 2012). Kandungan C-organik pada lahan yang digunakan $0.55 \%$ yang termasuk dalam kategori sangat rendah dan rasio $\mathrm{C} / \mathrm{N}$ dengan nilai 11 , termasuk sedang. Berdasarkan karakteristik kesesuaian lahan diketahui bahwa kesesuaian lahan untuk kedelai termasuk S3 (agak sesuai) dengan kendala KTK lahan yang sangat rendah. Noor (2007) menyatakan lahan rawa lebak dengan jenis tanah mineral mempunyai kandungan bahan organik yang rendah, KTK tanah rendah, namun ketersediaan hara sedang sampai tinggi. KTK tanah yang rendah menyebabkan mobilisasi hara rendah, kurang diserap oleh tanaman, walaupun hara yang tersedia di tanah dalam kondisi optimum. 


\section{Pertumbuhan Kedelai Fase Vegetatif Maksimum}

Tinggi tanaman kedelai pada fase vegetatif maksimum dengan perlakuan pupuk hayati lebih tinggi $(132.48 \mathrm{~cm})$ dibandingkan tanpa pupuk hayati $(125.85 \mathrm{~cm})$. Jumlah daun pada fase vegetatif maksimum dengan perlakuan pupuk hayati lebih banyak dibandingkan tanpa pupuk hayati. Perlakuan dosis pupuk N $22.50 \mathrm{~kg} \mathrm{ha}^{-1}$ menunjukkan jumlah cabang lebih banyak (3.87) dibandingkan tanpa pupuk $\mathrm{N}$ (Tabel 1).

Pupuk hayati yang digunakan mengandung bakteri penambat $\mathrm{N}$ dan pelarut $\mathrm{P}$ yang mampu meningkatkan kemampuan tanaman mengikat $\mathrm{N}$ dari udara dan dapat meningkatkan kelarutan fosfat di dalam tanah, sehingga fosfat menjadi tersedia bagi tanaman. Peningkatan dosis pupuk $\mathrm{N}$ juga menunjukkan pertambahan tinggi tanaman, jumlah daun dan jumlah cabang meskipun tidak berbeda nyata (Tabel 1). Pemberian pupuk $\mathrm{N}$ tidak selalu memberikan respon terhadap kenaikan hasil. Pengaruh pemupukan $\mathrm{N}$ terlihat pada warna daun kedelai menjadi hijau tua, pertumbuhan vegetatif bertambah, dan tanaman menjadi lebih tinggi.

Tinggi tanaman 4 MST yang diberi perlakuan kombinasi pupuk hayati $+11.25 \mathrm{~kg} \mathrm{~N} \mathrm{ha}^{-1}$, dan $72 \mathrm{~kg} \mathrm{P}_{2} 0_{5}$ $\mathrm{ha}^{-1}(48.73 \mathrm{~cm})$ dan kombinasi pupuk hayati $+22.50 \mathrm{~kg} \mathrm{~N}$ $\mathrm{ha}^{-1}+36 \mathrm{~kg} \mathrm{P}_{2} \mathrm{O}_{5} \mathrm{ha}^{-1}(48.67 \mathrm{~cm})$ lebih tinggi dibandingkan dengan kombinasi tanpa pupuk hayati $+33.75 \mathrm{~N} \mathrm{ha}^{-1}+$ $108 \mathrm{~kg} \mathrm{P}_{2} \mathrm{O}_{5} \mathrm{ha}^{-1}(40.87 \mathrm{~cm})$ dan kombinasi tanpa pupuk hayati, $22.50 \mathrm{~kg} \mathrm{~N}^{-1}$ dan tanpa pupuk $\mathrm{P}(40.73 \mathrm{~cm})$, tetapi tidak berbeda nyata dengan kontrol $(45.63 \mathrm{~cm})$. Kombinasi pupuk hayati $+11.25 \mathrm{~kg} \mathrm{~N} \mathrm{ha}^{-1}+72 \mathrm{~kg} \mathrm{P}_{2} \mathrm{O}_{5} \mathrm{ha}^{-1}$ $(48.73 \mathrm{~cm})$ menyebabkan tinggi tanaman 4 MST lebih tinggi dibanding kombinasi pupuk hayati $+33.75 \mathrm{~kg} \mathrm{~N} \mathrm{ha}^{-1}+108$ $\mathrm{kg} \mathrm{P}_{2} \mathrm{O}_{5} \mathrm{ha}^{-1}(43.73 \mathrm{~cm})$ tetapi tidak berbeda dengan kontrol $(42.80 \mathrm{~cm})($ Tabel 2$)$.

\section{Jumlah Cabang}

Jumlah cabang pada 10 MST dari kombinasi pupuk hayati $+22.50 \mathrm{~kg} \mathrm{~N} \mathrm{ha}{ }^{-1}+108 \mathrm{~kg} \mathrm{P}_{2} \mathrm{O}_{5} \mathrm{ha}^{-1}$ lebih tinggi dibandingkan kombinasi $11.25 \mathrm{~kg} \mathrm{~N} \mathrm{ha}^{-1}$ dan $72 \mathrm{~kg} \mathrm{P}_{2} \mathrm{O}_{5} \mathrm{ha}^{-1}$ dan kombinasi tanpa pupuk $\mathrm{N}$ dan $108 \mathrm{~kg} \mathrm{P}_{2} \mathrm{O}_{5} \mathrm{~kg} \mathrm{ha}^{-1}$ dan kontrol, tetapi tidak berbeda nyata dengan perlakuan tanpa hayati $11.25 \mathrm{~kg} \mathrm{~N} \mathrm{ha}^{-1}$ dan $36 \mathrm{~kg} \mathrm{P}_{2} \mathrm{O}_{5}$ $\mathrm{ha}^{-1}$ sehingga dosis ini direkomendasikan (Tabel 2). Jumlah cabang kedelai ditentukan oleh kontrol genetik (Kumudini et al., 2007) dan faktor lingkungan seperti kesuburan tanah. Jumlah cabang dan tinggi tanaman memberikan pengaruh langsung dan kontribusi positif yang cukup besar terhadap hasil kedelai (Hapsari et al., 2010).

\section{Jumlah Daun}

Jumlah daun 12 MST pada kombinasi dosis pupuk $33.75 \mathrm{~kg} \mathrm{~N}$ ha $^{-1}$ dan $108 \mathrm{~kg} \mathrm{P}_{2} \mathrm{O}_{5} \mathrm{ha}^{-1}$ berbeda nyata dibandingkan kombinasi $22.50 \mathrm{~kg} \mathrm{~N} \mathrm{Na}^{-1}$ dan $72 \mathrm{~kg} \mathrm{P}_{2} \mathrm{O}_{5} \mathrm{ha}^{-1}$. dan kombinasi $11.25 \mathrm{~kg} \mathrm{~N}^{-1}$ dan $36 \mathrm{~kg}$ ha $^{-1} \quad \mathrm{P}_{2} \mathrm{O}_{5}$ ha $^{-1}$ (Tabel 3). Jumlah daun memiliki peranan untuk dapat meningkatkan hasil kedelai karena fotosintesis terjadi di dalam daun. Daun merupakan organ tempat berlangsungnya fotosintesis sehingga secara tidak langsung memiliki peranan yang besar terhadap hasil kedelai (Sitompul dan Guritno, 1995).

\section{Bobot Kering Tajuk}

Bobot kering tajuk dengan perlakuan kombinasi pupuk hayati dan $108 \mathrm{~kg} \mathrm{P}_{2} \mathrm{O}_{5}$ ha $^{-1}$ lebih tinggi dibandingkan kombinasi pupuk hayati tanpa pupuk $\mathrm{P}$ dan kombinasi pupuk hayati $+72 \mathrm{~kg} \mathrm{P}_{2} \mathrm{O}_{5} \mathrm{ha}^{-1}$, tetapi tidak berbeda nyata dengan kontrol (Tabel 4). Salah satu fungsi pupuk P bagi tanaman

Tabel 1. Pertumbuhan tanaman kedelai di lahan rawa lebak pada umur 8 minggu setelah tanam

\begin{tabular}{|c|c|c|c|}
\hline Perlakuan & Tinggi tanaman $(\mathrm{cm})$ & Jumlah daun (helai) & Jumlah cabang (buah) \\
\hline \multicolumn{4}{|l|}{ Pupuk hayati } \\
\hline Tanpa pupuk hayati & $125.85 b$ & $23.82 b$ & $3.58 \mathrm{a}$ \\
\hline Pupuk hayati & $132.48 \mathrm{a}$ & $25.65 \mathrm{a}$ & $3.75 \mathrm{a}$ \\
\hline Tanpa pupuk N & $126.39 a$ & $24.57 b$ & $3.55 b$ \\
\hline $11.25 \mathrm{~kg} \mathrm{~N} \mathrm{ha}^{-1}$ & $126.93 \mathrm{a}$ & $23.88 b$ & $3.53 b$ \\
\hline $22.50 \mathrm{~kg} \mathrm{~N} \mathrm{ha}^{-1}$ & $129.30 \mathrm{a}$ & $24.07 \mathrm{~b}$ & $3.87 \mathrm{a}$ \\
\hline $33.75 \mathrm{~kg} \mathrm{~N} \mathrm{ha}^{-1}$ & $126.10 \mathrm{a}$ & $26.42 \mathrm{a}$ & $3.72 \mathrm{ab}$ \\
\hline Tanpa pupuk P & $127.80 \mathrm{a}$ & $23.49 b$ & $3.53 b$ \\
\hline $36 \mathrm{~kg} \mathrm{P}_{2} \mathrm{O}_{5} \mathrm{ha}^{-1}$ & $126.85 \mathrm{a}$ & $24.59 \mathrm{ab}$ & $3.73 \mathrm{ab}$ \\
\hline $72 \mathrm{~kg} \mathrm{P}_{2} \mathrm{O}_{5} \mathrm{ha}^{-1}$ & $128.13 \mathrm{a}$ & $25.24 \mathrm{a}$ & $3.60 \mathrm{~b}$ \\
\hline $108 \mathrm{~kg} \mathrm{P}_{2} \mathrm{O}_{5} \mathrm{ha}^{-1}$ & $125.94 \mathrm{a}$ & $25.61 \mathrm{a}$ & $3.80 \mathrm{a}$ \\
\hline
\end{tabular}

Keterangan: Angka yang diikuti huruf yang sama pada kolom dan faktor yang sama menunjukkan hasil yang tidak berbeda nyata berdasarkan DMRT pada $\alpha=5 \%$ 
Tabel 2. Pengaruh pupuk hayati, pupuk $\mathrm{N}$ dan pupuk $\mathrm{P}$ terhadap tinggi tanaman kedelai pada 4 minggu setelah tanam dan jumlah cabang 10 minggu setelah tanam

\begin{tabular}{|c|c|c|c|c|}
\hline \multirow{2}{*}{ Perlakuan } & \multicolumn{4}{|c|}{$\mathrm{P}_{2} \mathrm{O}_{5}$} \\
\hline & $0 \mathrm{~kg} \mathrm{ha}^{-1}$ & $36 \mathrm{~kg} \mathrm{ha}^{-1}$ & $72 \mathrm{~kg} \mathrm{ha}^{-1}$ & $108 \mathrm{~kg} \mathrm{ha}^{-1}$ \\
\hline & \multicolumn{4}{|c|}{ Tinggi tanaman 4 MST } \\
\hline \multicolumn{5}{|l|}{ Tanpa pupuk hayati } \\
\hline $0 \mathrm{~kg} \mathrm{~N} \mathrm{ha}^{-1}$ & 45.63abcd & 45.33abcd & 41.80de & $43.27 \mathrm{cde}$ \\
\hline $11.25 \mathrm{~kg} \mathrm{~N} \mathrm{ha}^{-1}$ & $44.00 \mathrm{bcde}$ & $43.67 \mathrm{bcde}$ & 45.60abcd & $43.87 \mathrm{bcde}$ \\
\hline $22.50 \mathrm{~kg} \mathrm{~N} \mathrm{ha}^{-1}$ & $47.87 \mathrm{ab}$ & 46.00abcd & 46.07abcd & $43.47 \mathrm{cde}$ \\
\hline $33.75 \mathrm{~kg} \mathrm{~N} \mathrm{ha-1}$ & 44.87abcde & 45.00abcde & 46.07abcd & $40.87 \mathrm{e}$ \\
\hline \multicolumn{5}{|l|}{ Pupuk hayati } \\
\hline 0 kg N ha ${ }^{-1}$ & $42.80 \mathrm{de}$ & 44.93abcde & $43.33 \mathrm{cde}$ & 45.87abcd \\
\hline $11.25 \mathrm{~kg} \mathrm{~N} \mathrm{ha}^{-1}$ & $42.80 \mathrm{de}$ & $43.80 \mathrm{bcde}$ & $48.73 \mathrm{a}$ & $47.20 \mathrm{abc}$ \\
\hline $22.50 \mathrm{~kg} \mathrm{~N} \mathrm{ha}^{-1}$ & $40.73 \mathrm{e}$ & $48.67 \mathrm{a}$ & $42.33 \mathrm{de}$ & 43.67bcde \\
\hline \multirow[t]{2}{*}{$33.75 \mathrm{~kg} \mathrm{~N} \mathrm{ha}^{-1}$} & $47.40 \mathrm{abc}$ & 44.87abcde & 45.80abcd & $43.73 \mathrm{bcde}$ \\
\hline & \multicolumn{4}{|c|}{ Jumlah cabang 10 MST } \\
\hline \multicolumn{5}{|l|}{ Tanpa pupuk hayati } \\
\hline $0 \mathrm{~kg} \mathrm{~N} \mathrm{ha-1}$ & $3.87 \mathrm{~d}$ & 4.40abcd & $4.20 \mathrm{abcd}$ & 4.40abcd \\
\hline $11.25 \mathrm{~kg} \mathrm{~N} \mathrm{ha}^{-1}$ & 4.20abcd & $4.27 \mathrm{abcd}$ & 4.20abcd & $4.13 \mathrm{abcd}$ \\
\hline $22.50 \mathrm{~kg} \mathrm{~N} \mathrm{ha}^{-1}$ & 4.40abcd & $4.20 \mathrm{abcd}$ & $4.53 \mathrm{ab}$ & 4.13abcd \\
\hline $33.75 \mathrm{~kg} \mathrm{~N} \mathrm{ha}^{-1}$ & $4.07 \mathrm{bcd}$ & 4.33abcd & $4.00 \mathrm{bcd}$ & 4.33abcd \\
\hline \multicolumn{5}{|l|}{ Pupuk hayati } \\
\hline 0 kg N ha-1 & 4.27abcd & $4.00 \mathrm{bcd}$ & 4.27abcd & $3.93 \mathrm{~cd}$ \\
\hline $11.25 \mathrm{~kg} \mathrm{~N} \mathrm{ha}^{-1}$ & $4.07 \mathrm{bcd}$ & 4.20abcd & $4.07 \mathrm{bcd}$ & $4.47 \mathrm{abc}$ \\
\hline $22.50 \mathrm{~kg} \mathrm{~N} \mathrm{ha}^{-1}$ & $4.07 \mathrm{bcd}$ & 4.40abcd & $4.47 \mathrm{abc}$ & $4.67 \mathrm{a}$ \\
\hline $33.75 \mathrm{~kg} \mathrm{~N} \mathrm{ha}^{-1}$ & $4.07 \mathrm{bcd}$ & $4.27 \mathrm{abcd}$ & $4.53 \mathrm{ab}$ & $4.53 \mathrm{ab}$ \\
\hline
\end{tabular}

Keterangan: Angka yang diikuti huruf yang sama menunjukkan hasil yang tidak berbeda nyata berdasarkan DMRT pada $\alpha=5 \%$

Tabel 3. Pengaruh utama pupuk hayati, pupuk $\mathrm{N}$ dan pupuk $\mathrm{P}$ terhadap jumlah daun

\begin{tabular}{|c|c|c|c|c|c|c|}
\hline \multirow{2}{*}{ Perlakuan } & \multicolumn{6}{|c|}{ Umur tanaman (MST) } \\
\hline & 2 & 4 & 6 & 8 & 10 & 12 \\
\hline \multicolumn{7}{|l|}{ Pupuk hayati } \\
\hline Tanpa hayati & 1.8 & $5.5 b$ & $16.3 \mathrm{~b}$ & $23.8 \mathrm{~b}$ & $26.6 b$ & 24.5 \\
\hline Pupuk hayati & 1.9 & $5.9 \mathrm{a}$ & $16.8 \mathrm{a}$ & $25.6 \mathrm{a}$ & $28.2 \mathrm{a}$ & 24.7 \\
\hline \multicolumn{7}{|l|}{ Pupuk N } \\
\hline $0 \mathrm{~kg} \mathrm{ha}^{-1}$ & 1.8 & 5.6 & 16.2 & $24.6 b$ & $26.8 b$ & $23.5 b$ \\
\hline $11.25 \mathrm{~kg} \mathrm{ha}^{-1}$ & 1.8 & 5.6 & 16.5 & $23.9 b$ & $26.8 b$ & $24.1 \mathrm{~b}$ \\
\hline $22.50 \mathrm{~kg} \mathrm{ha}^{-1}$ & 1.9 & 5.7 & 16.7 & $24.1 b$ & $26.8 b$ & $23.9 b$ \\
\hline $33.75 \mathrm{~kg} \mathrm{ha}^{-1}$ & 1.9 & 5.7 & 16.7 & $26.4 \mathrm{a}$ & $29.1 \mathrm{a}$ & $26.9 \mathrm{a}$ \\
\hline \multicolumn{7}{|l|}{ Pupuk P } \\
\hline $0 \mathrm{~kg} \mathrm{ha}^{-1}$ & 1.7 & 5.7 & 16.4 & $23.5 b$ & 26.7 & 25.0 \\
\hline $36 \mathrm{~kg} \mathrm{ha}^{-1}$ & 1.9 & 5.7 & 16.4 & $24.6 \mathrm{ab}$ & 27.1 & 24.1 \\
\hline $72 \mathrm{~kg} \mathrm{ha}^{-1}$ & 1.9 & 5.6 & 16.7 & $25.2 \mathrm{a}$ & 27.2 & 23.9 \\
\hline $108 \mathrm{~kg} \mathrm{ha}^{-1}$ & 1.9 & 5.7 & 16.6 & $25.6 \mathrm{a}$ & 28.5 & 25.3 \\
\hline
\end{tabular}

Keterangan: Angka yang diikuti dengan huruf yang sama pada kolom dan faktor yang sama tidak berbeda nyata berdasarkan uji DMRT pada taraf $5 \%$ 
adalah memperkuat batang agar tidak mudah roboh, untuk pembentukan bunga, buah, dan biji. Apabila proses fotosintesis berjalan dengan baik, maka bobot kering tajuk akan tinggi, artinya penyerapan hara berlangsung dengan baik. Tanaman dapat menyerap hara dengan baik sehingga menghasilkan biomassa yang besar.

\section{Kadar Hara N, P, dan K Daun Kedelai pada 8 MST}

Pemberian pupuk hayati berpengaruh nyata terhadap kadar $\mathrm{N}$ daun dengan kombinasi $108 \mathrm{~kg} \quad \mathrm{P}_{2} \mathrm{O}_{5} \quad \mathrm{ha}^{-1}$ dan berbeda nyata dengan tanpa pupuk hayati dan $108 \mathrm{~kg} \mathrm{P}_{2} \mathrm{O}_{5} \mathrm{ha}^{-1}$ (Tabel 4). Penggunaan pupuk hayati apabila dikombinasikan dengan pupuk $P$ akan meningkatkan kadar hara $\mathrm{N}$ pada tanaman kedelai. Hal ini sejalan dengan penelitian Fatima et al. ( 2007) yang menyatakan bahwa penambahan pupuk $\mathrm{P}$ dapat meningkatkan aktivitas nitrogenase pada rhizobium yang terdapat dalam pupuk hayati. Ghulamahdi et al. (2006) menyatakan serapan hara $\mathrm{N}, \mathrm{P}$, dan $\mathrm{K}$ daun kedelai pada sistem budidaya jenuh air lebih tinggi dibandingkan pada sistem budidaya jenuh-kering dan budidaya kering mulai umur 5-9 MST. Serapan N, P, dan K daun pada perlakuan budidaya jenuh air meningkat masingmasing sebesar $210.83 \%$, 203.51\% dan 218.62\%. Ketiga jenis pupuk tidak menunjukkan pengaruh yang berbeda nyata terhadap kadar hara N, P, dan $\mathrm{K}$ daun kedelai (Tabel 7). Batas kecukupan hara $\mathrm{N}$ untuk kedelai adalah $4.2 \%$ dan P sebesar $0.26 \%$ dan hara $\mathrm{K}$ sebesar $1.7 \%$ (Hardjowigeno, 2007). Pengaruh faktor tunggal pupuk $\mathrm{N}$ terhadap kadar ahar $\mathrm{N}$ dan $\mathrm{K}$ daun kedelai juga berbeda nyata dibandingkan tanpa pemberian pupuk N. Pupuk $\mathrm{P}$ berpengaruh terhadap kadar $\mathrm{P}$ dan $\mathrm{K}$ daun kedelai. Peningkatan dosis pupuk $\mathrm{P}$ meningkatkan kadar hara $\mathrm{P}$ dan $\mathrm{K}$ daun kedelai pada fase vegetatif maksimum (Tabel 8). Hasil analisis jaringan daun pada fase pertumbuhan vegetatif maksimum menunjukkan kadar hara N, P dan K pada daun di atas batas kecukupan, hal ini diperkirakan karena pengaruh pemberian pupuk hayati, pupuk $\mathrm{N}$ dan pupuk $\mathrm{P}$.

\section{Bobot Biji per Tanaman}

Bobot biji per tanaman tanpa pupuk hayati tidak berbeda nyata pada kombinasi pupuk $0 \mathrm{~kg} \mathrm{~N} \mathrm{ha-1,} 11.25$ $\mathrm{kg} \mathrm{N} \mathrm{Na}^{-1}$ dan $22.50 \mathrm{~kg} \mathrm{~N}^{-1}$ dan berbeda nyata pada perlakuan pupuk hayati dengan dosis $33.75 \mathrm{~kg} \mathrm{~N} \mathrm{ha}^{-1}$ (Tabel 5). Pemberian pupuk hayati dikombinasikan dengan pupuk $\mathrm{N}$ pada dosis $33.75 \mathrm{~kg} \mathrm{~N}^{-1}$ berpengaruh nyata terhadap bobot biji per tanaman.

Pengaruh ketiga jenis pupuk terhadap komponen hasil tidak memberikan perbedaan yang nyata, baik jumlah polong total, jumlah polong isi, jumlah polong hampa maupun produktivitas (Tabel 6). Hal tersebut kemungkinan disebabkan faktor sifat fisik dan kimia tanah sebelum penelitian yang sesuai untuk pertumbuhan tanaman kedelai dan tingkat kesuburan tanah yang sedang menyebabkan perlakuan tiga jenis pupuk tidak menujukkan hasil yang berbeda nyata terhadap produksi. Tanaman kedelai dapat tumbuh dengan baik pada tanah dengan $\mathrm{pH}$ 6.8-7.0, $\mathrm{N}$ total sedang, $\mathrm{P}_{2} \mathrm{O}_{5}$ tinggi, $\mathrm{K}_{2} \mathrm{O}$ sedang, $\mathrm{C}$-organik diatas $8 \%$ dengan tekstur tanah sedang (Djaenuddin et al., 1995). Jumlah hara

Tabel 4. Pengaruh interaksi pupuk hayati dengan pupuk $\mathrm{P}$ terhadap berat kering tajuk dan kadar hara $\mathrm{N}$ daun tanaman kedelai

\begin{tabular}{|c|c|c|c|c|}
\hline \multirow{2}{*}{ Perlakuan } & \multicolumn{4}{|c|}{$\mathrm{P}_{2} \mathrm{O}_{5} \mathrm{~kg} \mathrm{ha}^{-1}$} \\
\hline & 0 & 36 & 72 & 108 \\
\hline & \multicolumn{4}{|c|}{ Berat kering tajuk (g) } \\
\hline Tanpa pupuk hayati & $29.30 \mathrm{ab}$ & $26.84 \mathrm{ab}$ & $26.90 \mathrm{ab}$ & $26.93 \mathrm{ab}$ \\
\hline \multirow[t]{2}{*}{ Pupuk hayati } & $23.74 b$ & $29.48 \mathrm{ab}$ & $23.84 b$ & $30.79 a$ \\
\hline & \multicolumn{4}{|c|}{ Kadar hara N (\%) } \\
\hline Tanpa pupuk hayati & $4.44 b$ & $4.61 \mathrm{ab}$ & $4.64 \mathrm{ab}$ & $4.49 b$ \\
\hline Pupuk hayati & $4.58 b$ & $4.59 \mathrm{ab}$ & $4.66 \mathrm{ab}$ & $4.84 \mathrm{a}$ \\
\hline
\end{tabular}

Keterangan: Angka yang diikuti huruf yang sama menunjukkan hasil yang tidak berbeda nyata berdasarkan DMRT pada $\alpha=5 \%$

Tabel 5. Pengaruh pupuk hayati dengan pupuk $\mathrm{N}$ terhadap bobot biji per tanaman $(\mathrm{g})$

\begin{tabular}{lcccc}
\hline \multirow{2}{*}{ Perlakuan } & \multicolumn{3}{c}{$\mathrm{N}$} \\
\cline { 2 - 5 } & $0 \mathrm{~kg} \mathrm{ha}^{-1}$ & $11.25 \mathrm{~kg} \mathrm{ha}^{-1}$ & $22.50 \mathrm{~kg} \mathrm{ha}^{-1}$ & $33.75 \mathrm{~kg} \mathrm{ha}^{-1}$ \\
\hline Tanpa pupuk hayati & $21.71 \mathrm{a}$ & $19.41 \mathrm{ab}$ & $19.33 \mathrm{ab}$ & $16.39 \mathrm{~b}$ \\
Pupuk hayati & $19.66 \mathrm{ab}$ & $22.37 \mathrm{a}$ & $16.11 \mathrm{~b}$ & $21.61 \mathrm{a}$ \\
\hline
\end{tabular}

Keterangan: Angka yang diikuti huruf yang sama menunjukkan hasil yang tidak berbeda nyata berdasarkan DMRT pada $\alpha=5 \%$ 
yang tersedia dalam tanah sudah cukup untuk mendukung pertumbuhan dan produksi tanaman kedelai. Penambahan pupuk hayati, pupuk $\mathrm{N}$ dan pupuk $\mathrm{P}$ dapat meningkatkan serapan hara N, P, dan K oleh tanaman kedelai.

Kebutuhan hara $\mathrm{P}$ untuk kedelai relatif kecil daripada $\mathrm{N}$, K, atau $\mathrm{Ca}$, namun tanah di daerah tropis memerlukan fosfat dalam jumlah besar. Hasil penelitian ini menunjukkan bahwa pemberian pupuk $\mathrm{P}$ mampu meningkatkan jumlah polong total, jumlah polong isi, dan produktivitas tanaman. Oleh sebab itu, untuk mendapatkan hasil yang tinggi diperlukan hara dalam jumlah cukup dan seimbang, maka pemupukan $\mathrm{N}$ dan $\mathrm{P}$ harus seimbang dengan ketersediaan hara K. Manshuri (2010) menyatakan bahwa sampai dengan tingkat hasil tertentu kebutuhan optimal hara $\mathrm{N}$, P, dan $\mathrm{K}$ bagi tanaman kedelai berhubungan linier dengan hasil. Permadi (2014) menyatakan tanaman kedelai membutuhkan hara N, P, dan K dalam jumlah yang banyak untuk mencapai hasil yang tinggi. Kombinasi perlakuan tanpa pupuk hayati $+11.25 \mathrm{~kg} \mathrm{~N} \mathrm{ha}^{-1}$ dan $36 \mathrm{~kg}_{2} \mathrm{O}_{5} \mathrm{ha}^{-1}$ memberikan nilai terbaik untuk jumlah cabang, sedangkan untuk jumlah daun 12 MST adalah $33.75 \mathrm{~kg} \mathrm{~N} \mathrm{ha}{ }^{-1}+$ tanpa pupuk P. Untuk mendukung pertanian berkelanjutan dan berdasarkan hasil korelasi peubah pertumbuhan dan produksi, maka kombinasi pupuk hayati $+11.25 \mathrm{~kg} \mathrm{~N} \mathrm{ha}^{-1}$ dan $36 \mathrm{~kg} \mathrm{P}_{2} \mathrm{O}_{5}$ $\mathrm{ha}^{-1}$ direkomendasikan untuk lahan rawa lebak dangkal untuk meningkatkan kesuburan tanah.

Tabel 6. Keragaan komponen hasil tanaman kedelai pada berbagai perlakuan pemupukan

\begin{tabular}{lcccc}
\hline Perlakuan & $\begin{array}{c}\text { Jumlah polong total } \\
\text { (buah) }\end{array}$ & $\begin{array}{c}\text { Jumlah polong isi } \\
\text { (buah) }\end{array}$ & $\begin{array}{c}\text { Jumlah polong hampa } \\
\text { (buah) }\end{array}$ & $\begin{array}{c}\text { Produktivitas } \\
\text { (ton ha } \text { h }^{-1}\end{array}$ \\
\hline $\begin{array}{l}\text { Pupuk hayati } \\
\text { Tanpa pupuk hayati }\end{array}$ & 137.40 & 126.03 & 11.42 & 3.84 \\
Pupuk hayati & 145.81 & 129.66 & 12.73 & 3.88 \\
\hline Tanpa pupuk N & 139.15 & 125.18 & 10.12 & 3.61 \\
$11.25 \mathrm{~kg} \mathrm{~N} \mathrm{ha}^{-1}$ & 135.49 & 124.58 & 11.11 & 3.94 \\
$22.50 \mathrm{~kg} \mathrm{~N} \mathrm{ha}^{-1}$ & 140.94 & 126.44 & 12.10 & 4.00 \\
$33.75 \mathrm{~kg} \mathrm{~N} \mathrm{ha}^{-1}$ & 150.88 & 135.20 & 14.97 & 3.88 \\
\hline Tanpa pupuk P & 127.15 & 112.63 & 11.75 & 3.90 \\
$36 \mathrm{~kg} \mathrm{P}_{2} \mathrm{O}_{5} \mathrm{ha}^{-1}$ & 137.85 & 123.92 & 11.09 & 3.96 \\
$72 \mathrm{~kg} \mathrm{P}_{2} \mathrm{O}_{5} \mathrm{ha}^{-1}$ & 161.77 & 146.79 & 13.88 & 3.68 \\
$108 \mathrm{~kg} \mathrm{P}_{2} \mathrm{O}_{5} \mathrm{ha}^{-1}$ & 139.69 & 128.05 & 11.57 & 3.88 \\
\hline
\end{tabular}

Tabel 7. Serapan hara N, P dan K tanaman kedelai dari berbagai perlakuan pada umur 8 MST

\begin{tabular}{|c|c|c|c|}
\hline Perlakuan & Serapan N (g per tanaman) & Serapan P (g per tanaman) & Serapan K (g per tanaman) \\
\hline \multicolumn{4}{|l|}{ Pupuk hayati } \\
\hline Tanpa pupuk hayati & 0.389 & 0.035 & 0.162 \\
\hline Pupuk hayati & 0.401 & 0.036 & 0.171 \\
\hline \multicolumn{4}{|l|}{ Pupuk N } \\
\hline Tanpa pupuk N & 0.364 & 0.033 & 0.156 \\
\hline $11.25 \mathrm{~kg} \mathrm{~N} \mathrm{ha}^{-1}$ & 0.389 & 0.035 & 0.164 \\
\hline $22.50 \mathrm{~kg} \mathrm{~N} \mathrm{ha}^{-1}$ & 0.419 & 0.038 & 0.176 \\
\hline $33.75 \mathrm{~kg} \mathrm{~N} \mathrm{ha}^{-1}$ & 0.406 & 0.035 & 0.170 \\
\hline \multicolumn{4}{|l|}{ Pupuk P } \\
\hline Tanpa pupuk $\mathrm{P}$ & 0.366 & 0.031 & 0.149 \\
\hline $36 \mathrm{~kg} \mathrm{P}_{2} \mathrm{O}_{5} \mathrm{ha}^{-1}$ & 0.426 & 0.038 & 0.184 \\
\hline $72 \mathrm{~kg} \mathrm{P}_{2} \mathrm{O}_{5} \mathrm{ha}^{-1}$ & 0.421 & 0.037 & 0.173 \\
\hline $108 \mathrm{~kg} \mathrm{P}_{2} \mathrm{O}_{5} \mathrm{ha}^{-1}$ & 0.367 & 0.034 & 0.160 \\
\hline
\end{tabular}


Tabel 8. Pengaruh pupuk hayati, pupuk $\mathrm{N}$ dan pupuk P terhadap kadar hara daun 8 MST

\begin{tabular}{|c|c|c|c|}
\hline Perlakuan & $\mathrm{N}(\%)$ & $\mathrm{P}(\%)$ & $\mathrm{K}(\%)$ \\
\hline \multicolumn{4}{|l|}{ Pupuk hayati } \\
\hline Tanpa pupuk hayati & $4.54 b$ & 0.41 & $1.90 \mathrm{~b}$ \\
\hline Pakai pupuk hayati & $4.67 \mathrm{a}$ & 0.42 & $2.00 \mathrm{a}$ \\
\hline \multicolumn{4}{|l|}{ Pupuk N } \\
\hline Tanpa pupuk N & $4.39 b$ & 0.41 & $1.89 \mathrm{~b}$ \\
\hline $11.25 \mathrm{~kg} \mathrm{~N} \mathrm{ha}^{-1}$ & $4.64 a$ & 0.41 & $1.96 \mathrm{a}$ \\
\hline $22.50 \mathrm{~kg} \mathrm{~N} \mathrm{ha}^{-1}$ & $4.66 \mathrm{a}$ & 0.42 & $1.96 \mathrm{a}$ \\
\hline $33.75 \mathrm{~kg} \mathrm{~N} \mathrm{ha}^{-1}$ & $4.73 a$ & 0.41 & $1.98 \mathrm{a}$ \\
\hline \multicolumn{4}{|l|}{ Pupuk P } \\
\hline Tanpa pupuk & 4.51 & $0.39 \mathrm{c}$ & $1.85 \mathrm{c}$ \\
\hline $36 \mathrm{~kg} \mathrm{P}_{2} \mathrm{O}_{5} \mathrm{ha}^{-1}$ & 4.6 & $0.41 b$ & $1.98 \mathrm{ab}$ \\
\hline $72 \mathrm{~kg} \mathrm{P}_{2} \mathrm{O}_{5} \mathrm{ha}^{-1}$ & 4.65 & $0.42 b$ & $1.94 \mathrm{~b}$ \\
\hline $108 \mathrm{~kg} \mathrm{P}_{2} \mathrm{O}_{5} \mathrm{ha}^{-1}$ & 4.66 & $0.43 \mathrm{a}$ & $2.02 \mathrm{a}$ \\
\hline
\end{tabular}

Keterangan: Angka yang diikuti dengan huruf yang sama pada kolom dan faktor yang sama tidak berbeda nyata berdasarkan uji DMRT pada taraf $\alpha=5 \%$

\section{KESIMPULAN}

Pengaruh pupuk hayati, pupuk $\mathrm{N}$ dan pupuk $\mathrm{P}$ terhadap produktivitas kedelai di lahan rawa dengan tingkat kesuburan tanah sedang dan $\mathrm{pH}-\mathrm{H}_{2} 0$ 7.0 dan P-tersedia tinggi serta kandungan $\mathrm{K}_{2} \mathrm{O}$ sedang (26 mg $100 \mathrm{~g}^{-1}$ ) tidak berbeda nyata. Interaksi pupuk hayati dengan pupuk $\mathrm{N}$ meningkatkan bobot biji per tanaman dan interaksi pupuk hayati dan pupuk P meningkatkan bobot kering tajuk. Dosis yang direkomendasikan untuk pengembangan kedelai di lahan rawa lebak adalah pupuk hayati $+11.25 \mathrm{~kg} \mathrm{~N}^{-1}$ dan $36 \mathrm{~kg} \mathrm{P}_{2} \mathrm{O}_{5} \mathrm{ha}^{-1}$.

\section{UCAPAN TERIMAKASIH}

Terimakasih disampaikan kepada Badan Penelitian dan Pengembangan Pertanian atas bantuan biaya penelitian sesuai dengan SK Nomor : 146/Kpts/KU.010/I.1/04/2015 tanggal 13 April 2015.

\section{DAFTAR PUSTAKA}

[BPS]. 2016. Berita Resmi Statistik. [1 Nopember 2017].

[Balittanah]. 2012. Petunjuk teknis analisis kimia tanah, tanaman, air dan pupuk.

Djaenudin, D. 1995. Lahan marginal, tantangan, dan peluang pemanfaatannya. J. Penelitian dan Pengembangan Pertanian 4:35-47.

Fatimah, Z., M.Zia, M. F. Chaudhary. 2007. Interactive effect of Rhizobium strain and P on soybean yield, nitrogen fixation and soil fertility. Pak. J. Bot. 39:255-264.
Ghulamahdi, M., M. Melati, D. Sagala. 2009. Production of soybean varieties under soil culture on tidal swamps. J. Agron. Indonesian 37:226-232.

Ghulamahdi, M., S.A. Azis., M. Melati. 2006. Aktivitas nitrogenase, serapan hara dan pertumbuhan dua varietas kedelai pada kondisi jenuh air dan kering. Bul. Agron. 34:32-38.

Hapsari, T., M. Adie. 2010. Pendugaan parameter genetik dan hubungan antar komponen hasil kedelai. J. Penelitian Pertanian Tanaman Pangan 29:18-23.

Haryono, M. Noor, H. Syahbuddin, M. Sarwani. 2013. Lahan Rawa: Penelitian dan Pengembangan. IAARD Press. Badan Penelitian dan Pengembangan Pertanian. Kementerian Pertanian. Jakarta.

Harjowigeno, S. 2007. Ilmu Tanah. Akademika Pressindo. Jakarta.

Ilham, G., I.B. Darmayasa, I.M. Oka Nurjana, R. Kawuri. 2014. Isolasi dan identifikasi bakteri pelarut fosfat potensial pada tanah konvensional dan tanah organik. J. Simbiosis:1-6.

Kumudini, S., P. Pallikonda, C. Steele. 2007. Photoperiod and E-genes direcly influence the duration of soybean reproductive development. Crop Sci. 47:1510-1577.

Mulyani, A., M. Sarwani. 2013. Karakteristik dan potensi lahan sub optimal untuk pengembangan pertanian di Indonesia. J. Sumberdaya Lahan 7:47-55. 
Manshuri, A.G. 2010. Pemupukan N, P, dan K pada kedelai sesuai kebutuhan tanaman dan daya dukung lahan. J. Penelitian Pertanian Tanaman Pangan 29:171-179.

Mulyadi, A. 2012. Pengaruh pemberian legin, pupuk NPK (15:15:15) dan urea pada tanah gambut terhadap kandungan N, P total pucuk dan bintil akar kedelai (Glycine max L. Merril). J. Kaunia 7:21-29.

Noor, M. 2007. Rawa Lebak: Ekologi, Pemanfaatan dan Pengembangannya. PT. Raja Grapindo Persada. Jakarta.

Permadi, K. 2014. Implementasi pupuk N, P, dan K untuk mendukung swasembada kedelai. J. Agrotrop. 4:1-6.

Taufiq, A., A. Wijanarko, Suyamto. 2011. Takaran optimal pupuk NPKS dan pupuk kandang pada hasil kedelai di lahan pasang surut. J. Penelitian Pertanian Tanaman Pangan 30:143.
Taufiq, A., T. Sundari. 2012. Respon tanaman kedelai terhadap lingkungan tumbuh. Balai Penelitian Tanaman Kacang-kacangan dan Umbi-umbian. Pusat Penelitian Tanaman Pengembangan Tanaman Pangan. Buletin Tanaman Pangan 23:13-26.

Sagala, D., M. Ghulamahdi, M. Melati. 2011. Pola serapan hara dan pertumbuhan beberapa varietas kedelai dengan budidaya jenuh air di lahan pasang surut. J. Agroqua. 9:1-8.

Sitompul, S.M., B. Guritno. 1995. Analisa pertumbuhan tanaman. UGM Press, Jogyakarta.

Simanungkalit, R.D.M. 2001. Aplikasi pupuk hayati dan pupuk kimia:suatu pendekatan terpadu. Buletin Agrobiol 4:56-61. 